\title{
Renaissance of Brown Adipose Tissue
}

\author{
D. Tews M. Wabitsch \\ Division of Pediatric Endocrinology and Diabetes, Endocrine Research Laboratory, Department of Pediatrics and \\ Adolescent Medicine, University of Ulm, Ulm, Germany
}

\section{Key Words}

Brown adipose tissue $\cdot$ Thermoregulation $\cdot$ Recruitment

\begin{abstract}
The recent discovery of functional brown adipose tissue in human adults raised this tissue again into the focus of current investigations concerning human energy homeostasis. Brown fat is a key thermogenic tissue and is essential for nonshivering thermogenesis in the human newborn and hibernating mammals. This review highlights the biological and molecular aspects of brown adipose tissue development and function from the embryonic state to childhood and adolescence.

Copyright $\odot 2011$ S. Karger AG, Basel
\end{abstract}

\section{Introduction}

From the scientific point of view, brown adipose tissue (BAT) is a relatively new structure. When the Swiss researcher Konrad Gessner [1] in 1551 described the anatomy of the Alpine marmot (Marmota marmota), he found a tissue in its interscapular area which he described as being 'neither fat nor flesh' (nec pinguitudo, nec caro). Since then, researchers have tried to unravel its functional properties in mammals [2]. Until the beginning of the 19 th century, it was regarded as part of the thymus and

\section{KARGER}

Fax +41613061234

E-Mail karger@karger.ch

www.karger.com
(C) 2011 S. Karger AG, Basel

$1663-2818 / 11 / 0754-0231 \$ 38.00 / 0$

Accessible online at: www.karger.com/hrp later on it was recognized as a separate organ, but still as a ductless gland and part of the hematopoietic system. Up to the end of the 19th century, it was seen as a modified form of the adipose tissue. Until the middle of the 20th century, it was supposed to be an endocrine tissue. Not more than 50 years ago its function as a thermogenic tissue was discovered [3], which is commonly described as non-shivering thermogenesis (NST) [4]. It is defined as 'heat production due to metabolic energy transformation by processes that do not involve contraction of skeletal muscles, i.e. tone, microvibrations tremor (shivering), or tonic or voluntary contractions. NST increases in response to acute cold exposure. The principal effector organ is the BAT, which may adaptively increase its capacity for production in the course of acclimat(izat)ion and adaption to cold stress' [5]. In cold-acclimated rodents, norepinephrine-stimulated BAT dissipates energy by thermogenesis of about $300-400 \mathrm{~W} / \mathrm{kg}(0.3-0.4 \mathrm{~kJ} / \mathrm{s} / \mathrm{kg})$ of wet tissue mass [6-8]. It is estimated that $50 \mathrm{~g}$ of fully activated BAT could account for $20 \%$ of total energy expenditure in humans [9].

In the newborn child, BAT can be found in many different locations in the body, mostly around the vasculature and organs (table 1) [10]. These areas of deposition function in maintaining the body temperature during cold exposure by (a) warming the blood in surrounded blood vessels before its distribution to the periphery and (b) ensuring an optimal temperature for biochemical 
Table 1. Anatomical sites of BAT in children [10] and adults $[9,41$, 42]

\begin{tabular}{ll}
\hline Child & Adult \\
\hline $\begin{array}{l}\text { Interscapular } \\
\text { Supraclavicular }\end{array}$ & Supraclavicular \\
Axillary & Neck \\
Neck & Paravertebral \\
Suprarenal & Suprarenal \\
\hline
\end{tabular}

processes in adjacent organs. For these purposes and for the immense need of oxygen supply during NST, BAT is highly vascularized. Compared to white adipose tissue (WAT), the vascularity of this tissue is four to six times greater [11]. Additionally, BAT is highly innervated, predominantly by fibers of the sympathetic system. Several adipocytes with their adjoining capillaries and nerve fibers make up discrete lobules with thicker investments of connective tissue. The lobules themselves form lobes which account for the characteristic structure of adipose tissue [12]. The brown adipocyte itself is the predominant cell type of this organ. The cells are of polygonal shape containing numerous, large, cristae-filled mitochondria, a varying number of lipid droplets and few or no membranes in the cytoplasm (cf. fig. 2, multilocular fat cell).

The molecule responsible for thermogenesis is the uncoupling protein 1 (UCP-1), which is located in the inner membrane of mitochondria and makes up approximately $5 \%$ of total mitochondrial protein in brown adipocytes of cold-acclimated rodents [13]. It is uniquely found in BAT and in brown adipocytes [14]. Targeted disruption of UCP-1 in mice induced marked cold sensitivity in these animals, e.g. $85 \%$ of these mice were unable to maintain their body temperature during $24 \mathrm{~h}$ of cold exposure [15]. After activation, it dissipates the proton gradient that is generated by the mitochondrial respiratory chain by bypassing its normal coupling to the ATP synthase (fig. 1). In BAT, UCP-1 is inhibited by purine nucleotides and is activated by fatty acids. Therefore, its activation is coupled to lipolysis. During cold exposure, norepinephrine is released by sympathetic nerve endings and binds to $\beta_{3^{-}}$ adrenergic receptors on the surface of brown adipocytes. This leads to the activation of adenylyl cyclase and subsequently to a rise in cAMP levels. This in turn activates protein kinase $\mathrm{A}$, which further stimulates triglyceride breakdown by hormone-sensitive lipase. The precise mechanism of UCP-1 activation by fatty acids is not clear; however, there are theories that fatty acids can function either as allosteric regulators, cofactors or proton shuttles [16].

Thermogenesis of BAT is further enhanced via induction of UCP-1 expression by catecholamines and thyroid hormones. Activated protein kinase A phosphorylates deiodinases, which are highly expressed in BAT. This leads to a conversion of thyroxine into its active form triiodothyronine. This in turn amplifies catecholamine-induced UCP-1 expression by binding to its intracellular receptors and to thyroid hormone-sensitive elements in the UCP-1 promoter [17].

\section{BAT Evolution}

In mammals, BAT can be found amongst Eutheria and in marsupials [18], but not in Monotremata [19]. For these species, BAT allowed the successful radiation to cold environments, providing an evolutionary advantage. However, orthologs of UCP-1, which has been used as an evolutionary marker for BAT in many studies, are also present in fish and amphibians. The function of UCP-1 in these phyla is currently unknown.

The development of BAT in the different species among mammals is regulated due to their developmental status at birth [16]. Altricial newborns (e.g. rats, mice) are born with low amounts of BAT and the tissue is recruited during the first 5 days after birth. During cold exposure, brown fat tissue is recruited and BAT recruitment is inhibited in pups born at thermoneutral conditions. In some immature species such as the Syrian hamster, which are poorly developed in terms of thermoregulation, BAT develops only after the second week after birth. Before that, these animals are poikilotherm, i.e. not able to induce thermogenesis by themselves. In precocial mammals (lamb, guinea pig), BAT is already developed at birth and is activated or degraded in dependence of the environmental temperature. In terms of developmental aspects, humans belong to the altricial group; however, there is evidence that BAT is already well established in the fetus at the fifth month of gestation [20].

\section{BAT in the Fetus and the Child}

The development of BAT is tightly regulated in the human fetus and in the neonate reflecting the need of thermogenesis in the different stages of life. BAT develops in 
Fig. 1. Schematic view of mitochondrial respiratory chain uncoupling. In mitochondria of active brown adipocytes, the proton gradient established by the respiratory chain is uncoupled by UCP-1. This leads to the production of heat instead of production of ATP via ATP synthase. I = NADH dehydrogenase, II = succinate dehydrogenase, III = cytochrome bc $_{1}$ complex, IV = cytochrome $\mathrm{c}$ oxidase, $\mathrm{V}=\mathrm{ATP}$ synthase, $\mathrm{Q}=$ ubiquinone, cyt $\mathrm{c}=$ cytochrome c.

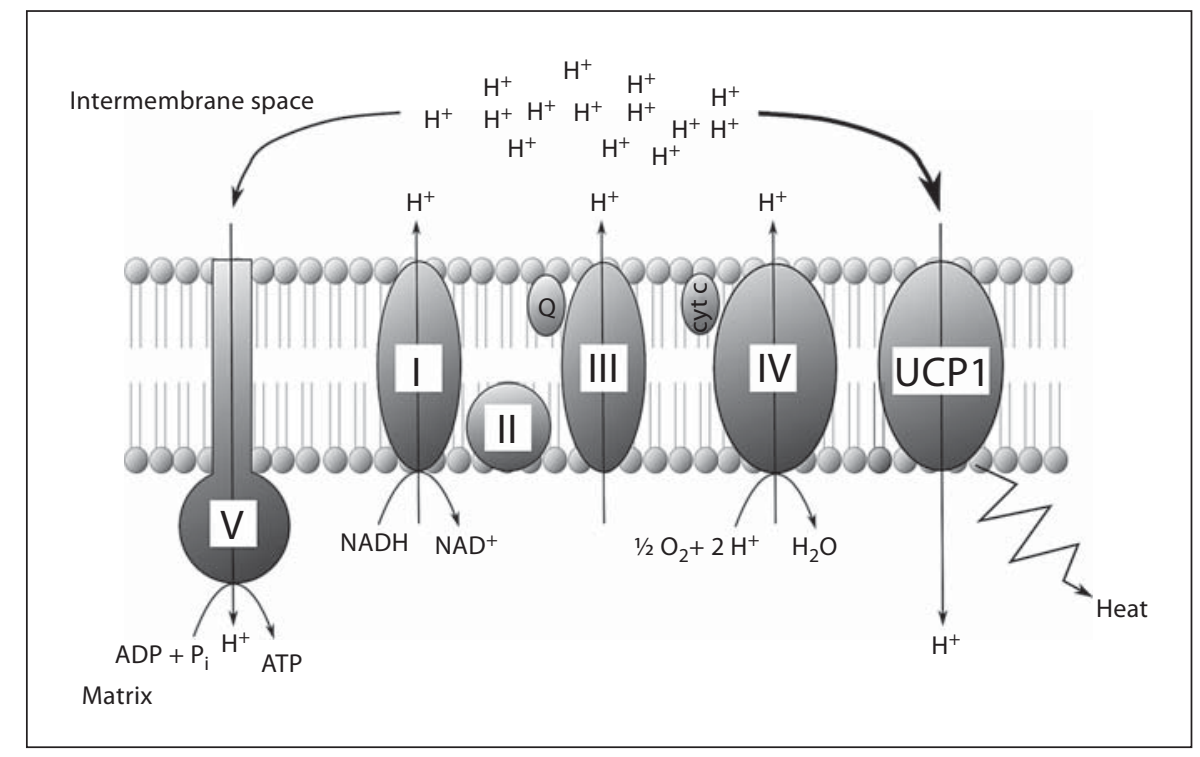

the fetus during gestation, and the amount of UCP-1 (as a marker of functional BAT) increases during fetal development. At the time of birth, UCP-1 abundance peaks, before declining over the first 9 months [21]. During intrauterine life, the fetus is warmed by its own metabolic processes. Studies in sheep calculated the metabolic rate of the fetus as being twice as high compared to adults [22]. The thermogenic control of the fetus is not well established and dependent on the mother, which leads to a constant temperature difference of $0.3-0.5^{\circ} \mathrm{C}$ between mother and fetus [23]. The temperature is in balance between fetal metabolic heat production and its dissipation to the mother, mainly by umbilical cord circulation and via the fetal skin [24]. Since NST is a process of high oxygen consumption, it has to be tightly inhibited in order to limit an excess demand for oxygen by BAT during fetal development. Indeed, it is suggested that NST is limited in the uterus, probably by an inhibitor [25]. Obvious candidates are circulating adenosine [26] and prostaglandin $\mathrm{E}_{2}[27,28]$ which both show antilipolytic properties in BAT.

At birth, the environment of the fetus switches from the warm uterine to the relatively cold extrauterine state with a change in temperature of more than $15^{\circ} \mathrm{C}$. Hypothermia can be lethal for neonates, with a higher risk for preterm infants. Mortality of neonates is markedly increased by even short periods of hypothermia and depends on its degree and duration [29, 30]. Compared to adults, newborns have several disadvantages regarding their maintenance of body temperature: the higher body surface-to-volume ratio together with the higher proportional surface of the head leads to more rapid heat loss. Due to low amount of muscle, the ability to induce thermogenesis by shivering is limited.

In children, BAT is found in several specific locations. A thin kite-shaped layer of BAT is present in the interscapular region. Another depot can be found in the axillae which is connected to lobes around the muscles and blood vessels of the neck by extensions passing under the clavicles. Smaller depots are extensions covering the vessels entering the thoracic inlet, masses in the mediastinum between the esophagus and trachea and sites in the abdomen which envelop the kidneys, adrenals, pancreas, autonomic ganglia and aorta [9].

The first evidence of BAT in neonates was described by Hatai in 1902 who found a tissue similar to the structure and location of BAT in hibernating animals. Later, these findings were confirmed by necropsy studies in a larger cohort of infants who died before the age of 4 weeks $[10,31]$. BAT was found in all 394 infants investigated [10]. Interestingly, in 42 infants, BAT was depleted of lipids due to either starvation (36 infants) or hypothermia (6 infants). Moreover, UCP-1 expression was shown in perirenal and axillary adipose tissue of infants which suggests that this tissue is thermogenically active. Indeed, signs of NST were shown in infants. During cold exposure, plasma glycerol levels rise in newborns without a change in plasma free fatty acids [32]. This suggests that lipolysis occurs in these neonates but fatty acids are retained in the adipose tissue for the induction of NST. This 
is supported by a study showing a higher temperature in the nape of the neck in human neonates during cold exposure [33].

Regarding older children, data in the literature is scarce. In anatomical studies, BAT can be found in children and adolescents [34]. Furthermore, UCP-1 activity was even higher in children compared to neonates in postmortem studies [21]. This seems to be controversial to the assumption that BAT is degraded during the first week after birth. As we will see in the next paragraph, even the existence of active brown fat in human adults is very likely.

\section{BAT in Adults}

For the last 30 years, the existence and functional activity of BAT in adult humans was quite unclear. It was doubted that BAT would contribute significantly to human thermogenesis, since adults are, compared to infants, able to shiver and to regulate their body temperature by behavior (clothing, etc.). However, the presence of BAT and UCP-1 was shown in studies conducted in the 1980s [21, 35-37], indicating the presence of BAT. Already in 1972, an anatomical dissection study with 52 persons aged between 0 and 80 years showed the existence of human BAT in all stages of life, but with significant decline of BAT depots with increasing age [34]. Additionally, patients with pheochromocytoma showed activation of BAT due to the hypersecretion of catecholamines [38, 39].

Recent findings of functional human BAT showed clearly that the presence of BAT in humans is not a curiosity of nature in a few cases but reflects the general situation. By combining CT scans and fluorodeoxyglucose positron emission tomography (FDG-PET), which is routinely used as a diagnostic instrument in cancer medicine, sites of high glucose uptake in areas which were earlier supposed to correlate with BAT, were identified. These areas included the supraclavicular, neck, paravertebral and suprarenal sites [40]. The proof that these sites are in fact BAT was shown 2 years later by 3 independent studies (table 1) $[9,41,42]$. In one study, sites of glucose uptake were found in 5 healthy subjects who were exposed to a relatively cold environment before the scans. In biopsies, cells with characteristic brown adipocyte morphology were found which expressed UCP-1 on RNA and protein level. Additionally, UCP-1 colocalized with mitochondrial markers [41]. Another study suggested that the amount of BAT was negatively correlated with
BMI. PET-CT scans were negative in some probands which were retested under thermoneutral conditions [42]. The third study was performed on scans taken at thermoneutrality for different diagnostic reasons of a larger cohort of men and women. The amount of positive scans was more than twofold higher (7.5\%) in women compared to men (3.1\%). Women appeared to have more BAT and higher FDG uptake activity [9].

In another recent study, samples from the perithyroid adipose tissue were taken from patients undergoing thyroid gland surgeries [43]. In one third of the patients, clusters of UCP-1-positive cells were found surrounded by white adipocytes. The appearance of BAT cells was negatively correlated to BMI and age. The areas of brown adipocytes were highly innervated suggesting a tight regulation of these cells even in adults. Additionally, brown precursor cells were found in this tissue, making a recruitment of BAT in the adult conceivable. In patients without brown adipocytes, the size of white adipocytes was significantly higher, without being influenced by BMI. The authors suggest that a certain fraction of humans switch during their life from a lean phenotype with small white adipocytes and BAT to an obese phenotype without BAT and larger adipocytes [43].

The correlation of BAT mass with age, sex and BMI was investigated in a retrospective study analyzing PETCT scans in a cohort of 3,604 patients undergoing these scans for a variety of diagnostic reasons [44]. Scans were taken without prior cold treatment and no data about UCP-1 expression was shown. BAT activity was negatively correlated with age and BMI, and women displayed higher activity compared to men. Similar relationships were found for BAT mass; however, there was no correlation with BMI. Since BAT activity is increased during cold exposure, there might also be seasonal influences on BAT recruitment. This was depicted in another study using PET-CT scans which showed a higher incidence of positive scans during autumn and winter [45].

All these reports demonstrate that BAT is present and active in adult humans. However, in some studies BAT activity was found in a minority (5-10\%) of scanned subjects only. Interestingly, another study demonstrated that PET-CT scans have a low reproducibility resulting in false-negative results under ambient temperature conditions, revealing that BAT is present in about one third of the population [46].

The impact of BAT on human energetics and its contribution to overall energy expenditure is quite unclear so far. This question needs to be resolved in order to elucidate the relation of BAT activity to obesity development. 
However, the recent findings of active BAT presence in adult humans have re-ignited the interest in the possibility to treat obesity by agents that recruit and activate BAT specifically. In the next paragraphs we will discuss the recent findings on the molecular regulation of BAT degeneration and recruitment.

\section{BAT Degeneration}

BAT is a highly dynamic organ and its mass is regulated via degeneration and recruitment processes. Apoptosis plays a major role in BAT degeneration and was shown to be induced by tumor necrosis factor- $\alpha$ (TNF- $\alpha$ ) in primary culture of rodent brown adipocytes [47, 48]. Interestingly, TNF- $\alpha$ levels are elevated in adipose tissue in a variety of obesity models and in obese humans [49].

The pathological state of obesity is connected to brown adipocyte apoptosis, at least in genetic models of obesity [47]. Interestingly, the amount of apoptotic brown adipocytes is higher in these animals compared to controls. This may lead to a loss of functionally active BAT and, therefore, to a disruption of NST. In turn, obese rats which were adapted to cold for several days displayed a reduced number of apoptotic brown adipocytes compared to rats kept at thermoneutrality [47]. According to those results, norepinephrine acted antiapoptotically both in cold [50] and in obesity [51]. In humans, no direct evidence of brown adipocyte apoptosis has been reported so far.

\section{Mechanisms of BAT Recruitment}

Thermogenesis in BAT is determined by its activity which can change rapidly. The capacity of thermogenesis is dependent on the recruitment of tissue, which might need days or even weeks to alter [16]. The activity is determined by the acute sympathetic stimulation, whereas the capacity is determined by the chronic rate of sympathetic stimulation.

Lineage studies with white and brown adipocytes could show that both cell types derive from different precursors. Brown adipocytes derive from a myoblast lineage from precursor cells of the dermomyotome (paraxial mesoderm), which express the marker myf5 (myogenic factor 5) [52]. In contrast, white adipocytes derive from the lateral mesoderm [53]. However, brown adipocytes can be found in WAT of rodents, and they are recruited in response to cold or catecholamines [54, 55]. Even in humans, brown adipocytes can be found in WAT $[56,57]$ and skeletal muscle [58]. Additionally, a study in mice showed that white adipocytes can convert directly into brown adipocytes by $\beta_{3}$-adrenergical mediated transdifferentiation [59]. These findings lead to a model of different 'types' of brown adipocytes: classical brown adipocytes which are derived from the myoblast lineage and brown cells which are either derived from precursors residing in the WAT or directly transdifferentiated from white adipocytes (fig. 2). The latter are called 'recruitable' [60], 'brite' [61] or 'beige' [62] adipocytes.

If we would like to induce brown adipocyte recruitment, it is necessary to understand the transcriptional networks in these cells. Early work had shown that the peroxisome proliferator-activated receptor- $\gamma$ (PPAR- $\gamma$ ) is a key regulator of both white and brown adipocytes. However, ectopic expression of PPAR- $\gamma$ in fibroblasts only gave rise to white adipocytes. A coactivator of PPAR$\gamma$, PPAR- $\gamma$ coactivator $1 \alpha$ (PGC- $1 \alpha)$, which is involved in mitochondrial biogenesis, induces UCP-1 expression in white adipocytes $[63,64]$. Deficiency of PGC-1 $\alpha$ has, however, no impact on the expression of brown fat selecting genes [65]. Transgenic expression of forkhead box C2 (FOXC2) was shown to induce the development of brown fat cells in WAT of mice together with an inhibition of insulin resistance and hypertriglyceridemia [66].

By using a genome-wide approach, another coactivator of PPAR- $\gamma$ was shown to act as a molecular switch between skeletal muscle and brown adipocytes $[67,68]$. PR domain zinc finger protein 16 (PRDM16) is highly expressed in brown adipocytes compared to white adipocytes. It forms a complex with C/EBP- $\beta$ which leads to enhanced expression of PPAR- $\gamma[69,70]$. By transgenic expression of both factors, mouse or human fibroblasts can be forced to display a brown phenotype. The factors influencing PRDM16 regulation or expression are currently unknown.

The involvement of the cyclooxygenase 2 (COX2) pathway in brown fat recruitment was shown by a recent study in mice [71]. By treatment with a $\beta_{3}$-receptor agonist or by cold induction, brown adipocyte recruitment was induced with a simultaneous induction of COX2 expression. Moreover, chronic transgenic overexpression of COX 2 protected these mice from diet-induced obesity and treatment of human preadipocytes with prostaglandins led to an induction of a brown adipocyte phenotype. The authors concluded that sympathetic stimulation shifts adipocyte progenitor cells to differentiate into a brown phenotype by COX 2 and downstream PPAR- $\gamma$ signaling [71]. 
Fig. 2. Adipocyte differentiation. Brown and white adipocytes originate from different progenitor lineages. BAT derives from myf5-positive cells from the paraxial mesoderm, whereas white adipocytes are differentiated from pericytes of the vasculature which originate from the lateral mesoderm. Additionally, white adipocytes might undergo transdifferentiation into 'brite' adipocytes. myf5 = Myogenic factor 5, $\mathrm{C} / \mathrm{EBP}=\mathrm{CAAAT}$ enhancer-binding protein, PPAR- $\gamma=$ peroxisome proliferator-activated receptor $\gamma$, PGC- $1 \alpha=$ PPAR$\gamma$ coactivator $-1 \alpha$, PRDM16 $=$ PR domain zinc finger protein 16, COX2 = cyclooxygenase 2, FOXC2 = forkhead box C2, STAT5 = signal transducer and activator of transcription 5, AP-1 = activating protein 1, SREBP-1 = sterol regulatory element-binding protein $1, \mathrm{KLF}=$ Krüppellike factor, BMP7 = bone morphogenic protein 7 .

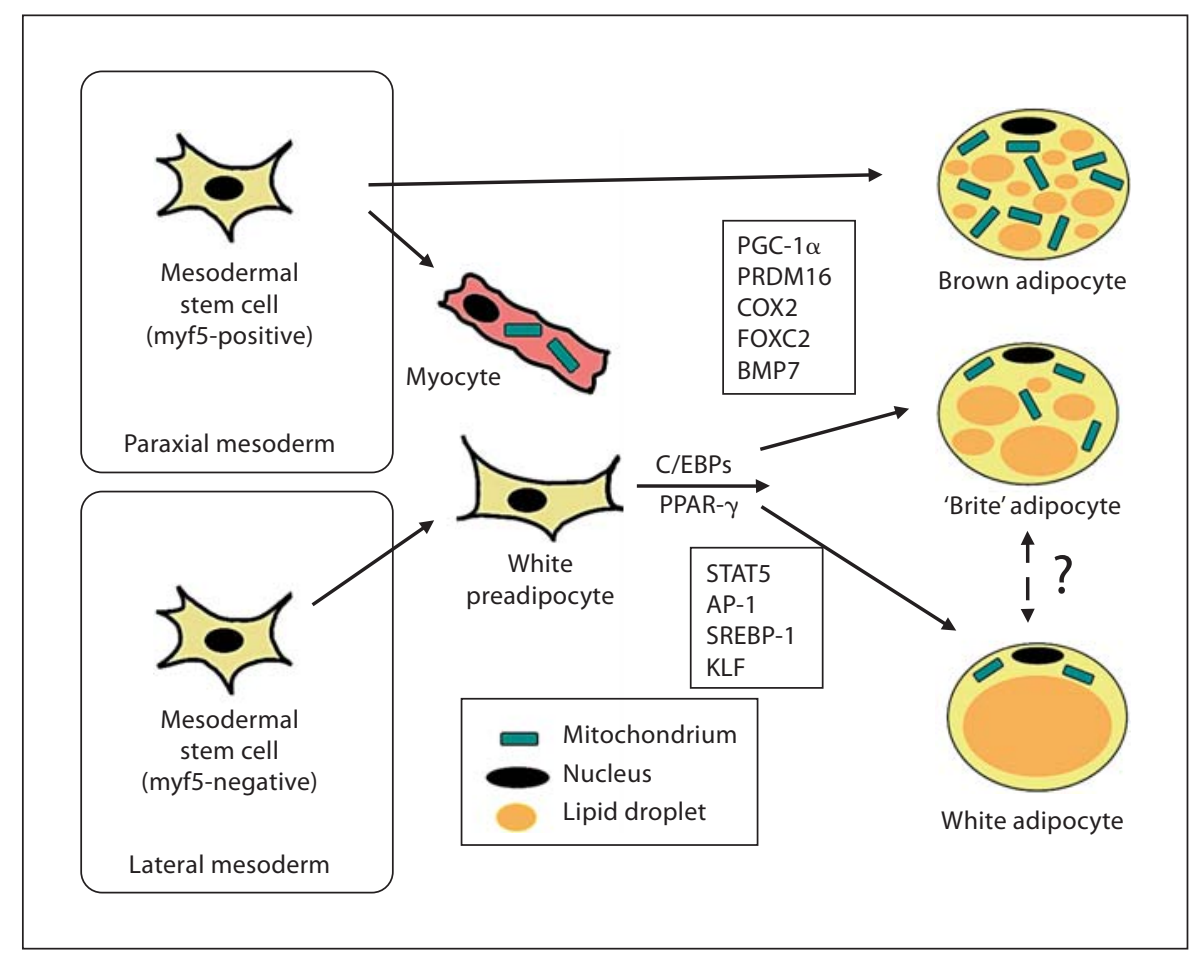

The role of bone morphogenic proteins in brown adipocyte recruitment was investigated in studies with mouse and human adipose progenitor cells $[72,73]$. These proteins belong to the transforming growth factor- $\beta$ superfamily and are involved in embryonic development and differentiation. It was demonstrated that bone morphogenic protein 7 (BMP7) is involved in brown preadipocyte differentiation and is able to induce UCP-1 expression in preadipocytes isolated from human subcutaneous adipose tissue [73].

\section{Pharmacologic Strategies Targeting BAT}

Due to its ability to enhance energy expenditure, BAT may serve as an important target for the development of therapeutics against obesity and its associated disorders. Reasonable strategies to combat obesity would then be to enhance either the recruitment or the activity (e.g. thermogenesis) of brown adipocytes. Several drug classes are currently under development aiming at BAT.

Thiazolidinediones (TZDs) are known to induce UCP1 expression in both brown and white adipocytes. Unfortunately, the use of TZDs implies the risk for side effects including increased adipose tissue mass and cardiac fail- ure. There is evidence that induction of UCP-1 by TZDs is mostly based on mitochondrial effects instead of their binding properties to PPAR- $\gamma$. Therefore, PPAR- $\gamma$-sparing TZDs are currently in clinical trails, which were shown to induce brown adipocyte differentiation of mouse precursor cells [74].

Ephedrine, a sympathomimetic obtained from Ephedra spp., was shown to activate BAT in rats [75]. In combination with caffeine it induces short-term weight loss [76]. Unfortunately, ephedrine is associated with increased risk of cardiac, psychoactive and gastrointestinal side effects. Agonists specific for the $\beta_{3}$-adrenergic receptor induced a marked thermogenic response in rodents [77]. However, these drugs failed to enhance energy expenditure in long-term clinical studies, probably due to a downregulation of $\beta_{3}$ effects [78]. Current approaches aim at selective thyroid hormone mimetics, which can promote fat loss in rodents without having severe side effects $[79,80]$.

A new role in thyroid hormone-mediated thermogenesis was recently found in response to bile acids, which enhance energy expenditure in BAT and enhance insulin sensitivity. These effects are mediated via a novel G-protein-coupled bile acid receptor (TGR5/GPBAR1) and the induction of the type 2 iodothyronine deiodinase (DIO2). 
This leads to an intracellular accumulation of bioactive triiodothyronine. In fact, the TGR5 agonist INT-777 reduced obesity of mice which were on a high-fat diet, and increased energy expenditure in primary brown adipocytes [81].

\section{Conclusion}

Recent demonstration of the existence of functionally active BAT in human adults has stimulated the scientific interest in this tissue which has been known for 500 years. Its functional significance for thermoregulation in humans and its implication in body weight regulation had been questioned in the past. Current research aims at understanding the regulation of BAT mass including the recruitment of brown adipocytes either from stem cells or by transdifferentiation of white adipocytes and apoptosis of brown adipocytes.

The investigation of the development of BAT during fetal life, infancy, childhood and adolescence will shed new light on the understanding of recruitment and degradation processes which might occur during this time. Moreover, the molecular pathways involved in BAT recruitment and activation which have been unraveled so far might lead to therapeutic targets.

\section{Acknowledgements}

We would like to thank Dr. P. Fischer-Posovszky and M. Keuper for the fruitful discussions and for proofreading the manuscript.

\section{References}

1 Gessner K: Historiae Animalium: Lib. I De Quadrupedibus viviparis, 1551.

$\checkmark 2$ Rasmussen A: The so-called hibernating gland. J Morphol 1923;38:147-205.

3 Smith R: Thermogenic activity of the hibernating gland in the cold-acclimated rat. Physiologist 1961;4:113.

4 Janský L: Non-shivering thermogenesis and its thermoregulatory significance. Biol Rev Camb Philos Soc 1973;48:85-132.

5 Simon E: Glossary of terms for thermal physiology. Pfluegers Arch 1987;410:567-587.

6 Foster DO, Frydman ML: Tissue distribution of cold-induced thermogenesis in conscious warm- or cold-acclimated rats reevaluated from changes in tissue blood flow: the dominant role of brown adipose tissue in the replacement of shivering by nonshivering thermogenesis. Can J Physiol Pharmacol 1979;57:257-270.

-7 Heldmaier G, Buchberger A: Sources of heat during nonshivering thermogenesis in Djungarian hamsters: a dominant role of brown adipose tissue during cold adaptation. J Comp Physiol B 1985;156:237-245.

8 Puchalski W, Böckler H, Heldmaier G, Langefeld M: Organ blood flow and brown adipose tissue oxygen consumption during noradrenaline-induced nonshivering thermogenesis in the Djungarian hamster. J Exp Zool 1987;242:263-271.

\9 Cypess AM, Lehman S, Williams G, Tal I, Rodman D, Goldfine AB, Kuo FC, Palmer EL, Tseng YH, Doria A, Kolodny GM, Kahn CR: Identification and importance of brown adipose tissue in adult humans. $\mathrm{N}$ Engl J Med 2009;360:1509-1517.
10 Aherne W, Hull D: Brown adipose tissue and heat production in the newborn infant. J Pathol Bacteriol 1966;91:223-234.

11 Hausberger FX, Widelitz MM: Distribution of labeled erythrocytes in adipose tissue and muscle in the rat. Am J Physiol 1963;204: 649-652.

12 Bargmann W, von Hehn G, Lindner E: On the cells of the brown fatty tissue and their innervation (in German). Z Zellforsch Mikrosk Anat 1968;85:601-613.

13 Stuart JA, Harper JA, Brindle KM, Jekabsons $\mathrm{MB}$, Brand MD: A mitochondrial uncoupling artifact can be caused by expression of uncoupling protein 1 in yeast. Biochem J 2001;356:779-789.

14 Trayhurn P: Uncoupling protein in brown adipose tissue: molecular differentiation of the adipose tissues. Biochem Soc Trans 1996; 24:402-406.

15 Enerbäck S, Jacobsson A, Simpson EM, Guerra C, Yamashita H, Harper ME, Kozak LP: Mice lacking mitochondrial uncoupling protein are cold-sensitive but not obese. $\mathrm{Na}-$ ture 1997;387:90-94.

16 Cannon B, Nedergaard J: Brown adipose tissue: function and physiological significance. Physiol Rev 2004;84:277-359.

17 Cannon B, Nedergaard J: Thyroid hormones: igniting brown fat via the brain. Nat Med 2010;16:965-967.
18 Jastroch M, Withers KW, Taudien S, Frappell $\mathrm{PB}$, Helwig M, Fromme T, Hirschberg V, Heldmaier G, McAllan BM, Firth BT, Burmester T, Platzer M, Klingenspor M: Marsupial uncoupling protein 1 sheds light on the evolution of mammalian nonshivering thermogenesis. Physiol Genomics 2008;32:161169.

19 Jastroch M, Withers K, Klingenspor M: Uncoupling protein 2 and 3 in marsupials: identification, phylogeny, and gene expression in response to cold and fasting in Antechinus flavipes. Physiol Genomics 2004;17:130-139.

20 Merklin RJ: Growth and distribution of human fetal brown fat. Anat Rec 1974; 178:637645.

21 Lean ME, James WP, Jennings G, Trayhurn $P$ : Brown adipose tissue uncoupling protein content in human infants, children and adults. Clin Sci 1986;71:291-297.

22 Power GG, Schröder H, Gilbert RD: Measurement of fetal heat production using differential calorimetry. J Appl Physiol 1984;57: 917-922.

-23 Gunn TR, Gluckman PD: Development of temperature regulation in the fetal sheep. J Dev Physiol 1983;5:167-179.

24 Gilbert RD, Schröder H, Kawamura T, Dale PS, Power GG: Heat transfer pathways between fetal lamb and ewe. J Appl Physiol 1985;59:634-638.

25 Asakura H: Fetal and neonatal thermoregulation. J Nippon Med Sch 2004;71:360-370.

-26 Sawa R, Asakura H, Power GG: Changes in plasma adenosine during simulated birth of fetal sheep. J Appl Physiol 1991;70:15241528. 
27 Takeuchi M, Yoneyama Y, Power GG: Role of prostaglandin $\mathrm{E}_{2}$ and prostacyclin in nonshivering thermogenesis during simulated birth in utero. Prostaglandins Leukot Essent Fatty Acids 1994;51:373-380.

-28 Yoneyama Y, Wakatsuki M, Sawa R, Kamoi S, Takahashi H, Shin S, Kawamura T, Power GG, Araki T: Plasma adenosine concentration in appropriate- and small-for-gestational-age fetuses. Am J Obstet Gynecol 1994; 170:684-688.

29 Watkinson M: Temperature control of premature infants in the delivery room. Clin Perinatol 2006;33:43-53, vi.

- 30 Costeloe K, Hennessy E, Gibson AT, Marlow N, Wilkinson AR: The EPICure study: outcomes to discharge from hospital for infants born at the threshold of viability. Pediatrics 2000;106:659-671.

-31 Aherne W, Hull D: The site of heat production in the newborn infant. Proc R Soc Med 1964;57:1172-1173.

- 32 Dawkins MJ, Scopes JW: Non-shivering thermogenesis and brown adipose tissue in the human newborn infant. Nature 1965; 206:201-202.

- 33 Silverman WA, Zamelis A, Sinclair JC, Agate FJ: Warm nap of the newborn. Pediatrics 1964;33:984-987.

34 Heaton JM: The distribution of brown adipose tissue in the human. J Anat 1972;112: 35-39.

-35 Bouillaud F, Villarroya F, Hentz E, Raimbault S, Cassard AM, Ricquier D: Detection of brown adipose tissue uncoupling protein mRNA in adult patients by a human genomic probe. Clin Sci 1988;75:21-27.

-36 Bouillaud F, Combes-George M, Ricquier D: Mitochondria of adult human brown adipose tissue contain a 32,000-Mr uncoupling protein. Biosci Rep 1983;3:775-780.

-37 Lean ME, James WP: Uncoupling protein in human brown adipose tissue mitochondria. Isolation and detection by specific antiserum. FEBS Lett 1983;163:235-240.

- 38 Lean ME, James WP, Jennings G, Trayhurn P: Brown adipose tissue in patients with phaeochromocytoma. Int J Obes 1986;10:219-227.

-39 Ricquier D, Nechad M, Mory G: Ultrastructural and biochemical characterization of human brown adipose tissue in pheochromocytoma. J Clin Endocrinol Metab 1982; 54:803-807.

40 Nedergaard J, Bengtsson T, Cannon B: Unexpected evidence for active brown adipose tissue in adult humans. Am J Physiol Endocrinol Metab 2007;293:E444-E452.

-41 Virtanen KA, Lidell ME, Orava J, Heglind $\mathrm{M}$, Westergren $\mathrm{R}$, Niemi T, Taittonen $\mathrm{M}$, Laine J, Savisto NJ, Enerback S, Nuutila P: Functional brown adipose tissue in healthy adults. N Engl J Med 2009;360:1518-1525.

-42 Van Marken Lichtenbelt WD, Vanhommerig JW, Smulders NM, Drossaerts JM, Kemerink GJ, Bouvy ND, Schrauwen P, Teule GJ: Coldactivated brown adipose tissue in healthy men. N Engl J Med 2009;360:1500-1508.
3 Zingaretti MC, Crosta F, Vitali A, Guerrieri M, Frontini A, Cannon B, Nedergaard J, Cinti S: The presence of UCP1 demonstrates that metabolically active adipose tissue in the neck of adult humans truly represents brown adipose tissue. FASEB J 2009;23:3113-3120.

44 Pfannenberg C, Werner MK, Ripkens S, Stef I, Deckert A, Schmadl M, Reimold M, Häring $\mathrm{H}$, Claussen CD, Stefan N: Impact of age on the relationships of brown adipose tissue with sex and adiposity in humans. Diabetes 2010;59:1789-1793.

45 Au-Yong ITH, Thorn N, Ganatra R, Perkins AC, Symonds ME: Brown adipose tissue and seasonal variation in humans. Diabetes 2009;58:2583-2587.

46 Lee P, Greenfield JR, Ho KK, Fulham MJ: A critical appraisal of prevalence and metabolic significance of brown adipose tissue in adult humans. Am J Physiol Endocrinol Metab 2010;299:E601-E606.

-47 Nisoli E, Briscini L, Tonello C, De GiuliMorghen C, Carruba MO: Tumor necrosis factor- $\alpha$ induces apoptosis in rat brown adipocytes. Cell Death Differ 1997;4:771-778.

48 Porras A, Alvarez AM, Valladares A, Benito M: TNF- $\alpha$ induces apoptosis in rat fetal brown adipocytes in primary culture. FEBS Lett 1997;416:324-328.

49 Hotamisligil GS: Mechanisms of TNF- $\alpha$-induced insulin resistance. Exp Clin Endocrinol Diabetes 1999;107:119-125.

50 Lindquist JM, Rehnmark S: Ambient temperature regulation of apoptosis in brown adipose tissue. Erk1/2 promotes norepinephrine-dependent cell survival. J Biol Chem 1998;273:30147-30156.

51 Briscini L, Tonello C, Dioni L, Carruba MO, Nisoli E: Bcl-2 and Bax are involved in the sympathetic protection of brown adipocytes from obesity-linked apoptosis. FEBS Lett 1998;431:80-84.

52 Atit R, Sgaier SK, Mohamed OA, Taketo MM, Dufort D, Joyner AL, Niswander L, Conlon RA: Beta-catenin activation is necessary and sufficient to specify the dorsal dermal fate in the mouse. Dev Biol 2006;296: 164-176.

53 Tang W, Zeve D, Suh JM, Bosnakovski D, Kyba M, Hammer RE, Tallquist MD, Graff JM: White fat progenitor cells reside in the adipose vasculature. Science 2008;322:583586.

54 Cousin B, Cinti S, Morroni M, Raimbault S, Ricquier D, Penicaud L, Casteilla L: Occurrence of brown adipocytes in rat white adipose tissue: molecular and morphological characterization. J Cell Sci 1992;103:931942.

55 Young P, Arch JR, Ashwell M: Brown adipose tissue in the parametrial fat pad of the mouse. FEBS Lett 1984;167:10-14.

56 Oberkofler H, Dallinger G, Liu YM, Hell E, Krempler F, Patsch W: Uncoupling protein gene: quantification of expression levels in adipose tissues of obese and non-obese humans. J Lipid Res 1997;38:2125-2133.
57 Garruti G, Ricquier D: Analysis of uncoupling protein and its $\mathrm{mRNA}$ in adipose tissue deposits of adult humans. Int J Obes Relat Metab Disord 1992;16:383-390.

58 Crisan M, Casteilla L, Lehr L, Carmona M, Paoloni-Giacobino A, Yap S, Sun B, Leger B, Logar A, Penicaud L, Schrauwen P, Cameron-Smith D, Russell AP, Peault B, Giacobino JP: A reservoir of brown adipocyte progenitors in human skeletal muscle. Stem Cells 2008;26:2425-2433.

-59 Barbatelli G, Murano I, Madsen L, Hao Q, Jimenez M, Kristiansen K, Giacobino JP, De Matteis R, Cinti S: The emergence of coldinduced brown adipocytes in mouse white fat depots is determined predominantly by white to brown adipocyte transdifferentiation. Am J Physiol Endocrinol Metab 2010; 298:E1244-E1253.

60 Enerback S: The origins of brown adipose tissue. N Engl J Med 2009;360:2021-2023.

61 Petrovic N, Walden TB, Shabalina IG, Timmons JA, Cannon B, Nedergaard J: Chronic PPAR- $\gamma$ activation of epididymally derived white adipocyte cultures reveals a population of thermogenically competent, UCP1containing adipocytes molecularly distinct from classical brown adipocytes. J Biol Chem 2009;285:7153-7164.

62 Koppen A, Kalkhoven E: Brown vs. white adipocytes: the PPAR- $\gamma$ coregulator story. FEBS Lett 2010;584:3250-3259.

-63 Puigserver P, Wu Z, Park CW, Graves R, Wright M, Spiegelman BM: A cold-inducible coactivator of nuclear receptors linked to adaptive thermogenesis. Cell 1998;92:829839.

64 Tiraby C, Tavernier G, Lefort C, Larrouy D, Bouillaud F, Ricquier D, Langin D: Acquirement of brown fat cell features by human white adipocytes. J Biol Chem 2003;278: 33370-33376.

65 Lin J, Wu PH, Tarr PT, Lindenberg KS, StPierre J, Zhang CY, Mootha VK, Jager S, Vianna CR, Reznick RM, Cui L, Manieri M, Donovan MX, Wu Z, Cooper MP, Fan MC, Rohas LM, Zavacki AM, Cinti S, Shulman GI, Lowell BB, Krainc D, Spiegelman BM: Defects in adaptive energy metabolism with CNS-linked hyperactivity in PGC- $1 \alpha$ null mice. Cell 2004;119:121-135.

66 Cederberg A, Gronning LM, Ahren B, Tasken K, Carlsson P, Enerback S: FOXC2 is a winged helix gene that counteracts obesity, hypertriglyceridemia, and diet-induced insulin resistance. Cell 2001;106:563-573.

67 Seale P, Kajimura S, Yang W, Chin S, Rohas LM, Uldry M, Tavernier G, Langin D, Spiegelman BM: Transcriptional control of brown fat determination by PRDM16. Cell Metab 2007;6:38-54.

68 Seale P, Bjork B, Yang W, Kajimura S, Chin S, Kuang S, Scime A, Devarakonda S, Conroe $\mathrm{HM}$, Erdjument-Bromage H, Tempst $\mathrm{P}$, Rudnicki MA, Beier DR, Spiegelman BM: PRDM16 controls a brown fat/skeletal muscle switch. Nature 2008;454:961-967. 
69 Kajimura S, Seale P, Tomaru T, ErdjumentBromage H, Cooper MP, Ruas JL, Chin S, Tempst P, Lazar MA, Spiegelman BM: Regulation of the brown and white fat gene programs through a PRDM16/CtBP transcriptional complex. Genes Dev 2008;22:13971409.

70 Kajimura S, Seale P, Kubota K, Lunsford E, Frangioni JV, Gygi SP, Spiegelman BM: Initiation of myoblast to brown fat switch by a PRDM16-C/EBP-beta transcriptional complex. Nature 2009;460:1154-1158.

-71 Vegiopoulos A, Müller-Decker K, Strzoda D, Schmitt I, Chichelnitskiy E, Ostertag A, Berriel Diaz M, Rozman J, Hrabe de Angelis M, Nüsing RM, Meyer CW, Wahli W, Klingenspor M, Herzig S: Cyclooxygenase-2 controls energy homeostasis in mice by de novo recruitment of brown adipocytes. Science 2010;328:1158-1161.

72 Tseng Y, Kokkotou E, Schulz TJ, Huang TL, Winnay JN, Taniguchi CM, Tran TT, Suzuki R, Espinoza DO, Yamamoto Y, Ahrens MJ, Dudley AT, Norris AW, Kulkarni RN, Kahn CR: New role of bone morphogenetic protein 7 in brown adipogenesis and energy expenditure. Nature 2008;454:1000-1004.
73 Schulz TJ, Huang TL, Tran TT, Zhang H, Townsend KL, Shadrach JL, Cerletti M, McDougall LE, Giorgadze N, Tchkonia T, Schrier D, Falb D, Kirkland JL, Wagers AJ, Tseng Y: Identification of inducible brown adipocyte progenitors residing in skeletal muscle and white fat. Proc Natl Acad Sci USA 2011; 108:143-148.

74 McDonald W, Cole S, Holewa D, BrightwellConrad A, Colca J, Kletzien R: Induction of brown adipose cell differentiation by the PPAR- $\gamma$-sparing thiazolidinediones. 70th Scientific Sessions of the American Diabetes Association, Orlando, June 25-29, 2010.

75 Baba S, Tatsumi M, Ishimori T, Lilien DL, Engles JM, Wahl RL: Effect of nicotine and ephedrine on the accumulation of ${ }^{18} \mathrm{~F}$-FDG in brown adipose tissue. J Nucl Med 2007;48: 981-986.

76 Boozer CN, Daly PA, Homel P, Solomon JL, Blanchard D, Nasser JA, Strauss R, Meredith T: Herbal ephedra/caffeine for weight loss: a 6-month randomized safety and efficacy trial. Int J Obes Relat Metab Disord 2002;26: 593-604.

77 Himms-Hagen J, Cui J, Danforth E, Taatjes DJ, Lang SS, Waters BL, Claus TH: Effect of CL-316,243, a thermogenic $\beta_{3}$-agonist, on energy balance and brown and white adipose tissues in rats. Am J Physiol 1994;266:R1371R1382.
8 Larsen TM, Toubro S, van Baak MA, Gottesdiener KM, Larson P, Saris WHM, Astrup A: Effect of a 28-day treatment with L-796568, a novel $\beta_{3}$-adrenergic receptor agonist, on energy expenditure and body composition in obese men. Am J Clin Nutr 2002;76:780-788.

79 Villicev CM, Freitas FRS, Aoki MS, Taffarel C, Scanlan TS, Moriscot AS, Ribeiro MO, Bianco AC, Gouveia CHA: Thyroid hormone receptor $\beta$-specific agonist GC-1 increases energy expenditure and prevents fat-mass accumulation in rats. J Endocrinol 2007;193: 21-29.

80 Bryzgalova G, Effendic S, Khan A, Rehnmark S, Barbounis P, Boulet J, Dong G, Singh R, Shapses S, Malm J, Webb P, Baxter JD, Grover GJ: Anti-obesity, anti-diabetic, and lipid-lowering effects of the thyroid receptor $\beta$-subtype-selective agonist KB-141. J Steroid Biochem Mol Biol 2008;111:262-267.

81 Thomas C, Gioiello A, Noriega L, Strehle A, Oury J, Rizzo G, Macchiarulo A, Yamamoto $\mathrm{H}$, Mataki C, Pruzanski M, Pellicciari R, Auwerx J, Schoonjans K: TGR5-mediated bile acid sensing controls glucose homeostasis. Cell Metab 2009;10:167-177. 